\title{
Anesthetic experimental device for small animal ${ }^{1}$
}

\author{
Aparelho de anestesia experimental para animais de pequeno porte
}

\author{
Luiz Alfredo de Magalhães Vivas², Nelson Jamel ${ }^{3}$, Ricardo Antonio Refinetti ${ }^{4}$, Luis Felipe da Silva ${ }^{4}$, Lígia Villela \\ Rodrigues $^{5}$, Paulo Cesar Silva ${ }^{6}$, Alberto Schanaider ${ }^{7}$ \\ 1. Research performed at Center of Experimental Surgery, Department of Surgery, Faculty of Medicine, Federal University of Rio de Janeiro (FM/ \\ UFRJ), Brazil. \\ 2. Assistant Professor, Department of Surgery, FM/UFRJ, Brazil. \\ 3. Full Professor and Head, Department of Surgery, FM/UFRJ, Brazil \\ 4. Full Professor, Department of Surgery, FM/UFRJ, Brazil. \\ 5. Medical student, FM/UFRJ, Brazil. \\ 6. Associate Professor, Department of Surgery, FM/UFRJ, Brazil. \\ 7. Associate Professor, Department of Surgery, Responsible for the Center of Experimental Surgery, FM/UFRJ, Brazil.
}

\begin{abstract}
Purpose: The difficulty to anesthetize small laboratory animals with vaporizer prompted us to go in search of new materials, and create new techniques. The improved equipment of anesthesia we looked for should be low cost, practical, versatile, and its management serve ethical, teaching, and research purposes. Methods: The new components of the equipment were: the vaporizer, the unidirectional valve, the glass cylinder filled with water, the flow guidance y-shape tube, the flow regulators, the mask modifications, and another free airway for emergency occurrence. A test was done with 30 Wistar rats, Rattus norvegicus albinus, divided into three groups with 10 rats for each one. Groups 1, 2 and 3 were anesthetized with Ether, Halothane and Sevoflurane respectively, using the new gadget. The anesthetic induction time, the breathing rhythm alteration during an anesthesia pre-established time (10 minutes), and the recovery time were observed. Results: The equipment enabled an easy handling, and fulfilled a larger safeness and stability during the induction and anesthetic management. The test showed it was possible to make use of several anesthetic agents. Conclusion: The device is effective, and turns the anesthesia procedure into a very easy practice with low-cost. It should be recommended for experimental surgery, teaching and research.
\end{abstract}

Key words: Anesthesia, Inhalation. Equipment Design. Experimental Development. Rats.

\section{RESUMO}

Objetivos: As dificuldades evidenciadas no uso de vaporizadores para anestesia em animais de pequeno porte motivaram o aperfeiçoamento e a criação de novos componentes técnicos visando a construção de um aparelho de anestesia de baixo custo, prático e versátil no manuseio e que atenda aos preceitos éticos do ensino e da pesquisa. Métodos: Utilizaram-se 30 ratos da linhagem Wistar, Rattus norvegicus albinus, distribuídos em três grupos. Grupo 1,2 e 3 (n=10, cada), compreenderam o uso do novo aparelho aduzido, respectivamente, do Éter; Halotano e Sevoflurano. Foram verificados o tempo de indução anestésica, as alterações do ritmo ventilatório durante o tempo de manutenção anestésica (préestabelecido em 10 min) e o tempo de recuperação anestésica. O aparelho foi construído com dispositivos técnicos novos sobressaindo: o vaporizador, a válvula unidirecional na campânula, o cilindro de vidro com água, o tubo direcionador de fluxo em forma de Y, os reguladores de fluxo, as modificações na máscara e a entrada de ar, independente, para situações emergenciais. Resultados: O aparelho permitiu um fácil manuseio e propiciou uma maior segurança e estabilidade na indução e manutenção anestésicas possibilitando, inclusive, a utilização de vários agentes anestésicos. Conclusão: $\mathrm{O}$ aparelho demonstrou ser útil para anestesia em cirurgia experimental, facilitando a realização dos procedimentos de pesquisa e de ensino de forma mais prática, eficiente, segura, e com baixo custo.

Descritores: Anestesia por Inalação. Desenho de Equipamento. Desenvolvimento Experimental. Ratos. 


\section{Introduction}

Usual laboratory procedures to anesthetize small animals prove to be unsatisfactory for the supply of volatile pain reducing drugs and for they do not exhibit easy and efficacious control on the anesthetic. An outstanding technical system should be low cost, able to adjust dosing to specific levels and versatile to volatile drug management. The device we describe is an evolution of the classical anesthesia procedure through which, rats, mice, and other small animals are fast asleep by breathing inhalation drugs in a confined area.

\section{Methods}

\section{The equipment}

The present study was approved and licensed ( $N^{\circ} 27 /$ 2005) by the Ethics Committee for the Use of Laboratory Animals on Researching, Teaching and Extension Activities (CEPAL), of the Faculty of Medicine of the Federal University of Rio de Janeiro. The new built up device (Figure 1) comprised: an induction chamber (1) with a three-way unidirectional key (2), a glass cylinder partially filled with water (3), a compressor (4), one flow conductor with a y-shape connected to a two regulators clamps (5), a management plastic made hood (6), and a laboratory tube (7) containing a needle $(40 \times 12 \mathrm{~mm})$ where the volatile anesthetic drug is placed. The induction plastic chamber (1) shape was cubic $(17,8 \times 17,8 \times 17,4 \mathrm{~cm})$, and had a volume of $3.880 \mathrm{ml}$; a three-way key (2) in the lid diverted the anesthetic flow either to the induction chamber or to the management hood. A hand-made unidirectional outlet valve (3) in the plastic lid enabled the carbonic gas $\left(\mathrm{CO}_{2}\right)$ produced by the animal to escape (Figure 2). The vaporizer (Figure 3) was made of: a laboratory test tube (1) filled with the anesthetic drug; an adhesive tape used to fasten the stopper to the tube (2), a 40x12"needle (3) connected to the compressor inserted into the stopper, with its cutting edge pushed down to the bottom of the tube inside a glass cylinder partially filled with water. The compressor was a simple aquarium air-compressing machine pump coupled to a plastic tube with a threeway key which is responsible to conduct the flow from that pump machine to the vaporizer or through another tube acting, in case of emergency, as an ambient air exit directly connected with the hood. There is also a Y-shape flow conductor connected to the two flow regulators: a first clamp just after one arm of the $\mathrm{Y}$ conductor and a second one downstream in order to adjust the admission flux of volatile anesthetic drugs (Figure 4). The flow of compressed air from the anesthetic chamber was calibrated to two liter/min through an airflowmeter. A plastic container commonly used as a slide box in pathology laboratory served as anesthetic hood. Two holes were made in the bottom of this hood, one to let in

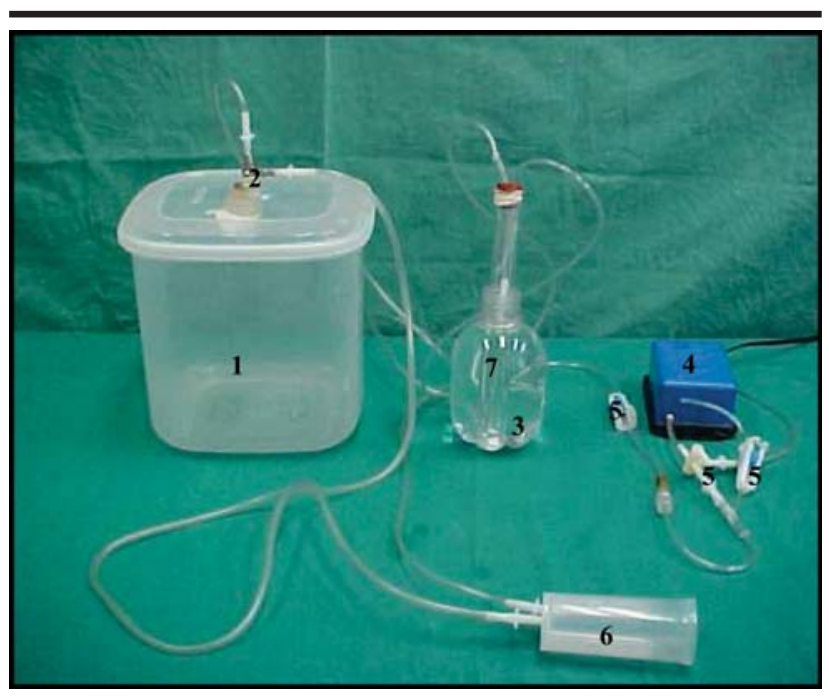

FIGURE 1 - The anesthetic equipment: (1) the induction chamber; (2) three way unidirectional key; (3) the glass cylinder partially filled with water containing the tube with the anesthetic drug; (4) the air compressing machine; (5) the y-shaped tube an two regulators; (6) the management plastic hood; (7) the laboratory tube with the needle.

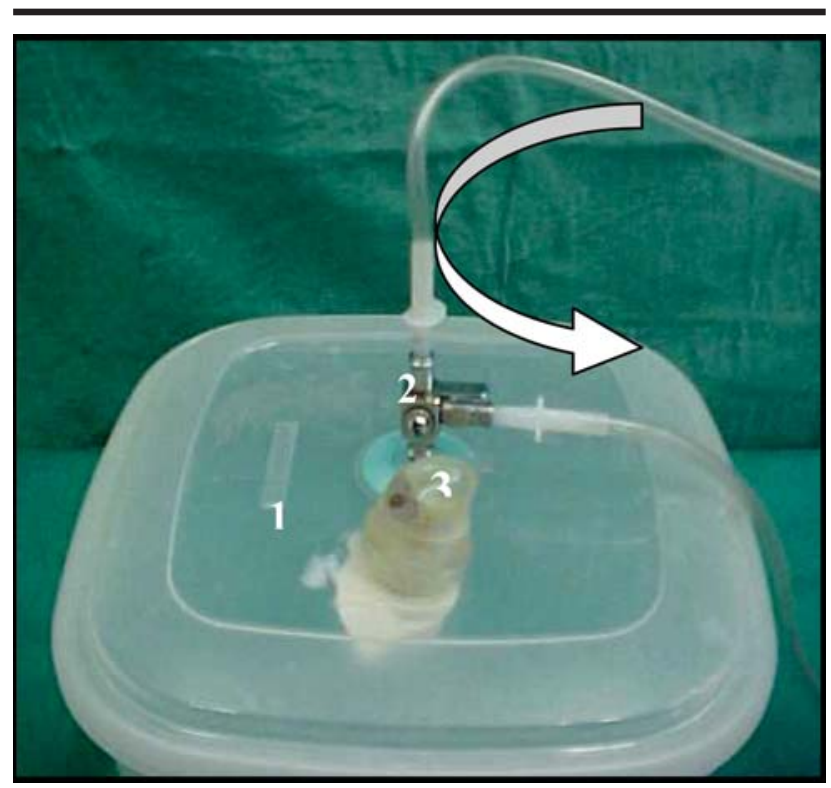

FIGURE 2 - Features of the induction chamber. The arrows show the flow direction

the anesthesia flow, and the other for an emergency airflow that comes from the compressor. Three others in its lateral part were created and worked as air outlet to prevent carbonarcosis or excess of anesthetic as this occurs in simple laboratory procedure (Figure 5). By starting up the machine the air stream crossed the first three way key, next, flew through the Y-shape tube, and finally reached the volatile anesthetic drug through the needle in the vaporizer. Then bubbles were produced by the airflow streamed upwards in the tube filled with the anesthetic liquid. Hereafter the vaporized anesthetic flew 
either to the induction chamber or to the hood for management according to the anesthetic objective.

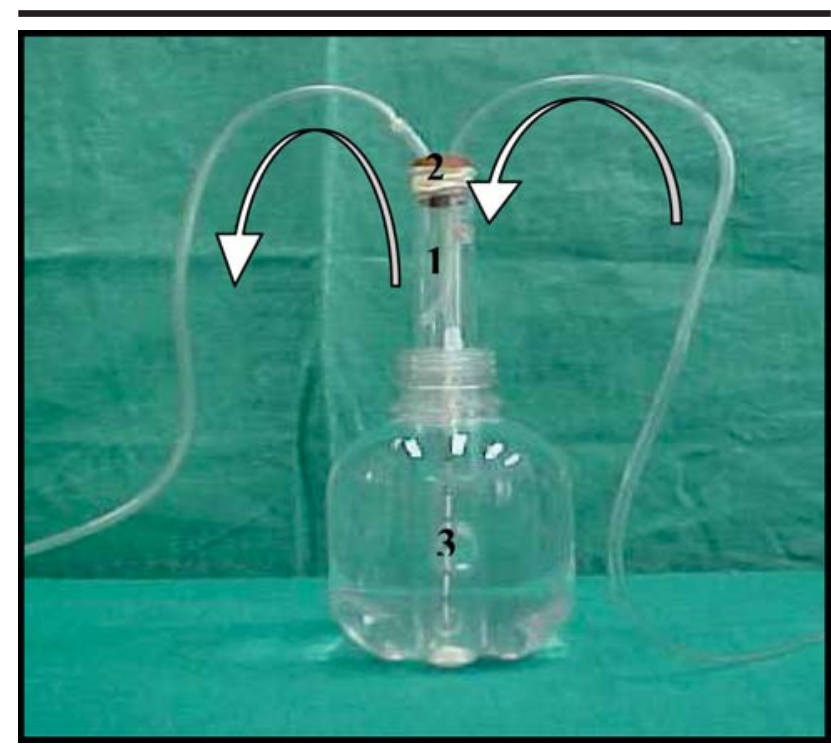

FIGURE 3 - More details of the vaporizer. The arrows show the flow

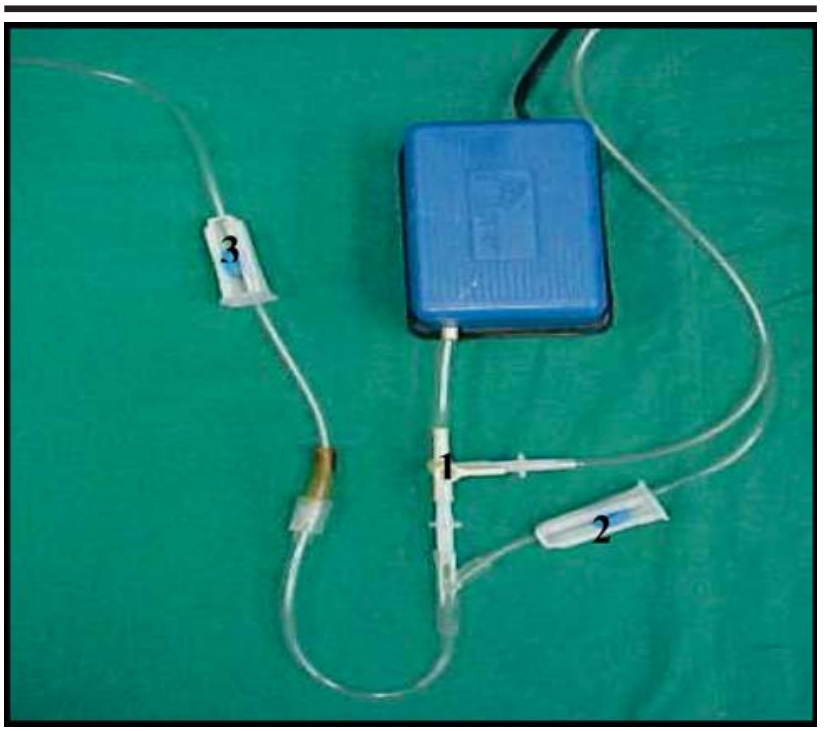

FIGURE 4 - The y-shaped tube (1) and two flow regulators $(2,3)$ are seen. The arrows show the flow direction

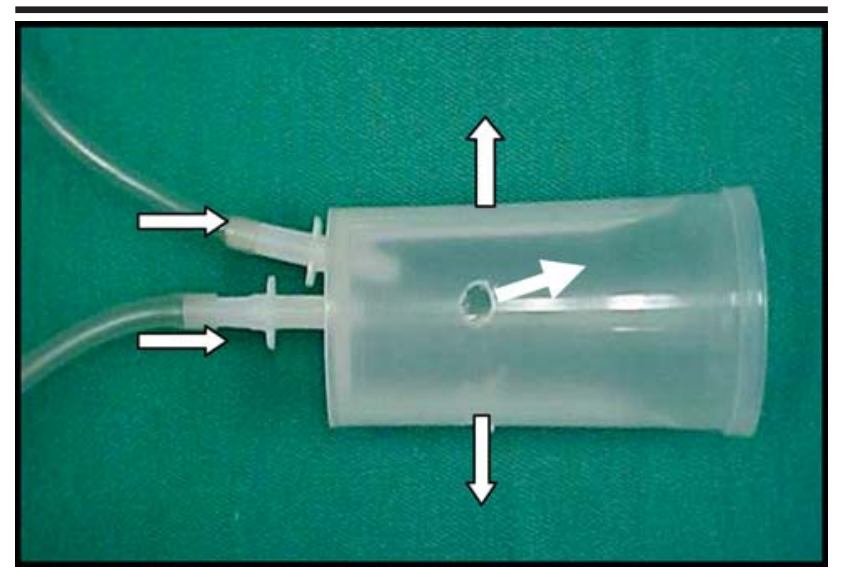

FIGURE 5 - Anesthetic plastic hood. The arrows show the flow direction.

\section{The experiment}

An anesthetic experimental test was done on a group of 30 Wistar rats (Rattus norvegicus albinus), weighing 180 to $250 \mathrm{~g}$, raised in appropriate environmental conditions, and fed with industrialized pellets. The animals were anesthetized by using the device with Ethyl Ether, Halothane and Sevoflurane, respectively for groups 1, 2 and 3 (10 rats each). The experiment was done by using the induction chamber of the equipment. This was not previously saturated with the anesthetics but received an anesthesia flow regulated accordingly to the property of the drugs (Ethyl Ether, Halothane and Sevoflurane). The time period rated from the moment that the animal was placed in the induction chamber till the anesthesia stage achievement when the animal fell asleep was named the anesthetic induction time. After the anesthesia stage the animal was removed from the induction chamber, transferred to a surgical table, and his head set into the anesthetic hood for the necessary management. The abdominal and axillaries areas of his body were pinched with tweezers to test for muscle pain reflexes. A 10-minute standardized time period during which the rat was maintained into the anesthesia hood was named the anesthesia management time. The time period rated from the end of the anesthetic process, when the animal was withdrawn from the anesthesia hood, and transferred from to the surgery table to a cage, till its normal behavior recovery, was named the anesthetic recovery time. The Student t test and the Dunn method were applied to appraise the differences in the means or median values among the following treatment groups: induction time, management and recovery times. For multiple comparison procedure the Kruskal-Wallis One Way analysis of variance on ranks was used. Statistically significant difference between input groups was admitted for a probability $\mathrm{p} \leq 0,05$.

\section{Results}

The results of the induction and recovery times obtained with different anesthetics administered according to laboratory procedure and with the equipment are shown in Tables 1 and 2, respectively. Two rats died during the Halothane induction time due to cardiac depression. Significant induction time differences $(p<0.01)$ among the Ethyl Ether anesthetized rat group and the other groups were obtained using the device (Table 3). There was no significance among the Halothane and the Sevoflurane anesthetized rat groups. 
TABLE 1 - Induction time (in seconds)

\begin{tabular}{rccc}
\hline RATS & Ethyl Éther & $\begin{array}{c}\text { Halothane } \\
\text { With the Equipment }\end{array}$ & Sevoflurane \\
\hline $\mathbf{1}$ & 240 & 120 & 135 \\
$\mathbf{2}$ & 420 & $\#$ & 160 \\
$\mathbf{3}$ & 240 & $\#$ & 140 \\
$\mathbf{4}$ & 180 & 130 & 120 \\
$\mathbf{5}$ & 420 & 180 & 160 \\
$\mathbf{6}$ & 180 & 160 & 140 \\
$\mathbf{7}$ & 240 & 160 & 150 \\
$\mathbf{8}$ & 360 & 180 & 180 \\
$\mathbf{9}$ & 420 & 140 & 135 \\
$\mathbf{1 0}$ & 600 & 150 & 160 \\
\hline$\#=$ rats died & & & \\
\hline
\end{tabular}

TABLE 2 - Anesthetic recovery time (in seconds)

\begin{tabular}{rccc}
\hline RATS & Ethyl Ether & $\begin{array}{c}\text { Halothane } \\
\text { With the Equipment }\end{array}$ & Sevoflurane \\
\hline $\mathbf{1}$ & 180 & 120 & 145 \\
$\mathbf{2}$ & 240 & $\#$ & 110 \\
\hline $\mathbf{3}$ & 240 & $\#$ & 120 \\
$\mathbf{4}$ & 180 & 180 & 110 \\
\hline $\mathbf{5}$ & 300 & 300 & 120 \\
$\mathbf{6}$ & 180 & 180 & 120 \\
$\mathbf{7}$ & 240 & 180 & 120 \\
$\mathbf{8}$ & 180 & 300 & 195 \\
$\mathbf{9}$ & 240 & 180 & 190 \\
$\mathbf{1 0}$ & 300 & 120 & 120 \\
\hline
\end{tabular}

\# = rats died previously, during induction

TABLE 3 - Rats anesthetized with different drugs using the device procedure

\begin{tabular}{|c|c|c|c|c|}
\hline \multicolumn{5}{|c|}{ INDUCTION TIME IN SECONDS } \\
\hline Anesthetics & Rats & Median & Min & Max \\
\hline a Ethyl Ether & 10 & 300 & 180 & 600 \\
\hline b Halothane & 8 & 155 & 120 & 180 \\
\hline c Sevoflurane & 10 & 145 & 135 & 180 \\
\hline \multicolumn{5}{|c|}{ RECOVERY TIME IN SECONDS } \\
\hline Anesthetics & Rats & Median & Min & Max \\
\hline d Ethyl Ether & 10 & 240 & 180 & 600 \\
\hline e Halothane & 8 & 180 & 120 & 300 \\
\hline f Sevoflurane & 10 & 120 & 110 & 195 \\
\hline
\end{tabular}

$\mathrm{p}<0.01$ for $(\mathrm{a} \times \mathrm{b}),(\mathrm{a} \times \mathrm{c}),(\mathrm{d} \times \mathrm{e})$ and $(\mathrm{d} \times \mathrm{f})$

\section{Discussion}

The low cost, easy handling, and the ability to provide good analgesia level besides fast anesthetic recovery makes the Ethyl Ether an anesthetic drug universally used in experimental surgery 1,2,3,4,5, However Ethyl Ether is extremely dangerous as it is harmful when absorbed by ingestion, inhalation or even by the skin. In addition, peroxides formation is favored when Ethyl Ether is exposed to ambient air ${ }^{6,7,8}$. In the most traditional technique also 
denominated conventional type or the pervaded wads anesthetizing system, the concentration of the Ether inside of a closed mask rises abruptly with excessive saturation level with carbonarcosis ${ }^{2,3}$ and adverse inflammatory effects on the mucous membrane of the trachea and bronchi. In consequence an excessive tracheobronchial mucus secretion causes hypoxia and subsequent respiratory blockade during the recovery time. It could results on the death of the animals and demands a careful management. Thus Ether is no longer the best anesthetic choice. The Halothane and Sevoflurane did not produce bronchial secretion as seen with Ethyl Ether. By them, induction and recovery times were reduced $(\mathrm{p}<0.01)$ in relation to Ether times. Considering that these two parameters having kept inexpressive statistical differences among them, we succeeded in getting a normal and stable anesthetic flow for the equipment vaporizer which certainly would be an advantage in laboratory anesthesia. The cardiac depression death of the two Halothane anesthetized rats were attributed to the experiments during which big bubbles were formed in the vaporizer tube and the first induction flows were tested $^{9,10}$. We suggest the formation of medium size bubbles for the induction time and small ones for the anesthesia management hood when using this kind of anesthetic. The equipment gained an undeniable advantage over the common laboratory process as it enabled visual control over the anesthetic flow by using a simple magnifying system. The presence of the laboratory tube associated to a bubble size enlarging glass filled with water allows to better control of the size of the bubbles. It also helps to keep steady the anesthetic vaporizer pressure. In some way the system prevented local anesthetic saturation that may occur in other equipments. Another interesting new gadget was the Yshaped tube and the flow regulators. These three components contribute to control the flow from the compressor, to achieve more bubbling accuracy and finally to stabilize the pressure. It is also an essential part of the equipment to reducing the flow without switching off the compressor. The Sevoflurane was considered a good anesthetic even better than the Halothane ${ }^{8,9}$. It is easily transformed by the liver and the environment being less toxic to the animals. As a result it is gives to the operator a confident and serene proceeding by the stability of the vaporizer, the induction chamber, and the management hood.

\section{Conclusion}

The device is effective, ethical and had low-cost, and it turns the anesthesia procedure into a very easy practice for small animal's surgery research and teaching.

\section{References}

1. Silva PC. Aparelho vaporizador para a anestesia em camundongos, ratos e coelhos. Rev Med Cir. 1991; 3:89-94.

2. Brito MVH. Modificação do vaporizador artesanal de éter para cirurgia experimental. Rev Bras Anestesiol. 1999; 49: 107-9.

3. Brito MVH. Vaporizador artesanal de éter para cirurgia experimental em pequenos roedores. Acta Cir Bras. 1998; 13: 3-5.

4. Souza F, Paes AMA, Alves HFP, Siroti FJ, Mathias PCF. Vaporizador de éter para cirurgia experimental em ratos. Acta Cir Bras. 1997; 12: 270-2.

5. Lee DK, Terrazas RG, Votto LG, Arenson-Pandikow H. Técnica de indução inalatória em ratos: estudo comparativo. Acta Cir Bras 1994; 9: 34-7.

6. Scheffer A. Anesthesia and sedation. In: Gay WI. Methods of animal experimentation. 1ed. New York: Academic Press; 1965. p.66-70.

7. White PF, Johnston RR, Eger EI. Determination of anesthetic requirement in rats. Anesthesiology., 1974; 40:52-7.

8. Woodard G. Principles in drug administration choice of animal species. In: Gay WI. Methods of animal experimentation. 1ed. New York: Academic Press; 1965. p.357.

9. Goodman LS, Gilman A. As bases farmacológicas da terapêutica. Rio de Janeiro: Guanabara Koogan; 1996.

10. Marshall S, Milligan A, Yates R. Experimental techniques and anaesthesia in rat and mouse. ANZCCART News. 1994; 7:1-4.

\section{Correspondence:}

Luiz Alfredo de Magalhães Vivas

Universidade Federal do Rio de Janeiro

Centro de Cirurgia Experimental, Bloco J / $2^{\circ}$ andar

21944-970 Rio de Janeiro - RJ Brazil

Phone: (55 21)9982-2711 / 815-2271

anestvivas@yahoo.com.br
Conflict of interest: none Financial source: none

Received: January 15, 2007

Review: February 12, 2007

Accepted: March 16, 2007

\section{How to cite this article}

Vivas LAM, Jamel N, Refinetti RA, Silva LF, Rodrigues LV, Silva PC, Schanaider A. Anesthetic experimental device for small animal. Acta Cir Bras. [serial on the Internet] 2007 May-June;22(3). Available from URL: http://www.scielo.br/acb 